\title{
Forest West African indigenous diet and modernization diseases
}

\author{
Chidi G. Osuagwu
}

Department of Biomedical Technology, Federal University of Technology, Owerri Imo State, Nigeria

Corresponding author: Chidi G Osuagwu, $\mathrm{PhD}$, Department of Biomedical Technology, Federal University of Technology, Owerri, Imo State, Nigeria

Submission Date: November $13^{\text {th }}$, 2019. Acceptance Date: December $28^{\text {th }}$, 2019. Publication Date: December $30^{\text {th }}, 2019$.

Citation: Osuagwu CG. Forest West African Indigenous Diet and Modernization Diseases. Functional Foods in Health and Disease 2019; 9(12): 772-787. DOI: 10.31989/ffhd.v9i12.673

\begin{abstract}
This review paper notes that the nutritional essence of an indigenous people's diet can, broadly, be outlined in terms of their food-inherent bioactive chemical functions. Two food crops; Yam (Dioscorea spp.) and the Oil-palm (Elaeis guineensis), define Forest West Africa, agriculturally, as Yam or Palm belt. They can also be said to, broadly, define the diet of the region, which staple base they constitute, as the Yampalm Diet type. Some unique, bioactive, chemical functions of yam identified include; dioscorin, lipoic acid, potassium, biotin and, thiocyanate, while those of oil-palm include; tocotrienols, carotenoids, retinoids and lauric acid. These alkalizing food functions are, in theory, complementary to the acidic tropical physiology of Forest West Africans. Fed on other than the Yampalm diet, Forest West Africans have been demonstrated to be highly susceptible to metabolic syndrome, and some other diseases, due to adopted alien diets. Examples are lactose intolerance from milk and inflammation reaction to wheat gluten. Some food functions of Yampalm diet; dioscorin in yam and tocotrienol from oil-palm, as examples, are efficacious in metabolic syndrome management. They are potential 'Gene-adapted food-function supplements' for emigrants from this area who adopt alien diets. Experiments have shown that restoration of the Forest West African diet ameliorates metabolic syndrome among the people, including their Diaspora in America. Restoration of, genetically or epigenetically, adapted indigenous diet among peoples recommends itself as part of management strategy for modernization diseases.
\end{abstract}

Key terms: Yampalm diet, food function, dioscorin, tocotrienol, alien diet, lactose intolerance, metabolic syndrome, epigenetic adaptation.

\section{INTRODUCTION}

\section{Environmental Adaptation and Diet}

A given people, over a sufficiently long time, genetically or epigenetically, adapt to their environment. Because the environments of the Earth's surface which humans inhabit are highly 
variable, the adaptive variations in human biology reflect, also, in variations in energy and biostructural material needs. Energy and biostructural needs are, in turn, reflected in the adapted diets [1]. The explanations for these human variations are encoded in a set of rules or laws called biogeographic or ecogeographic laws. These laws explain variations along latitudes and altitudes $[2,3,4,5,6]$. These variations in human energy and material needs are tied to food use or diet types of different peoples.

\section{Ecogeography and Diet Types}

Diet types have come, for ecogeographic reasons, to be associated with particular geographic areas or regions of the world. The most famous, and best known, diet in the world at this time is the Mediterranean Diet, which is noted to be healthful [7]. Within Europe, there is also the Scandinavian diet, adapted to the colder and less humid climate of Scandinavia. Compared to the Mediterranean, the Scandinavian diet is known to be heavier in calories [8]. This is why the calorielower Mediterranean diet is usually recommended to those who would want to lose weight. Forest West Africa; in the hot and humid tropics, has a unique diet associated with it.

\section{THE YAMPALM DIET OF FOREST WEST AFRICA World Cradles of Crop Domestication.}

The Mideast, called the Fertile Crescent, is the best-publicized center of crop domestication in the world [9]. The iconic crop of Middle-east fertile Crescent crop domestication is Wheat. But there are others; a key one in each major continent, as wheat represents Eurasian crop domestication. Each ancient cradle of crop domestication in the world has a flagship Crop associated with it.

Asian flagship crop is rice; Oryza sativa [10]. North America has maize; Zea mays [11]. South America has potato (Solanum tuberosum) [12], and cassava; Manihot esculenta [13]. In Africa, outside the Egyptian Nile valley that is regarded as part of the Middle-eastern Fertile Crescent, the other area regarded as a major cradle of crop domestication is the West African Niger basin. The flagship crops of Forest West Africa are the yam; Dioscorea rotunda [14] and oil palm (Elaeis guineensis). The important African rice, for grassland grain eaters, was also domesticated in West Africa, but not Forest West Africa [15].

\section{Chemical Functional Essences of Yam as a Dietary Item.}

From the biogeographic arguments, forest West Africans are tropical peoples. They have less need for energy generation to warm their bodies. So, they would not need fast-digesting, acidifying, food; with a high glycemic index. Yam has a moderate glycemic index [16]. With lower metabolic rate, and greater need to cool down in a hot environment, Forest West Africans need, on average, less food. With a more acidic body, they would require a diet whose main staple would be alkalizing. Yam, as expected, excels in its content of the powerful alkalizer mineral, Potassium [17].

Apart from quality as major alkalizer, yam has some other essential nutrients that are very suited to the Forest West African body system (Figure 1-4).

With good 'chemical eyes', one notices that what all the above molecules that are essential chemical functions'; nutrients, in yam, have in common is richness in easy to release electrons. Apart from the many electron-rich double bonds, the two elements Nitrogen, N, and Sulphur, S, 
that are common in them are well-known carriers of free electron pairs. Free electron-pairs are electrons that can easily be used to neutralize an acid. And they can be released in a modulated, stepwise, fashion. This is why both $\mathrm{N}$ and $\mathrm{S}$ can form multiple bonds as well as exist in multiple oxidation states. They are, like potassium, strong alkalizing agents. In effect, the ancestral domesticators of yam had picked the best possible crop out of their environment for the acidic Forest West African body system.

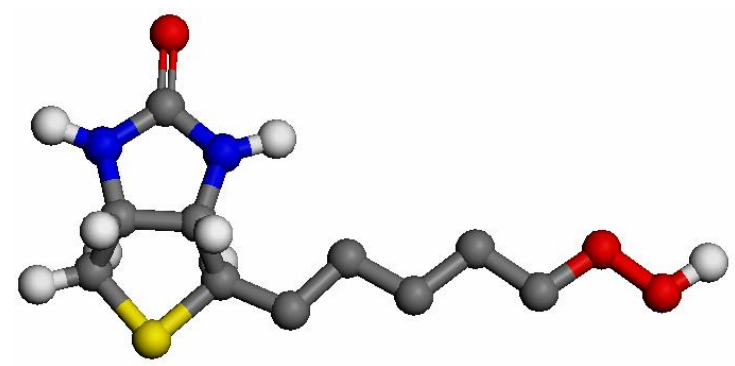

Figure 1: Biotin

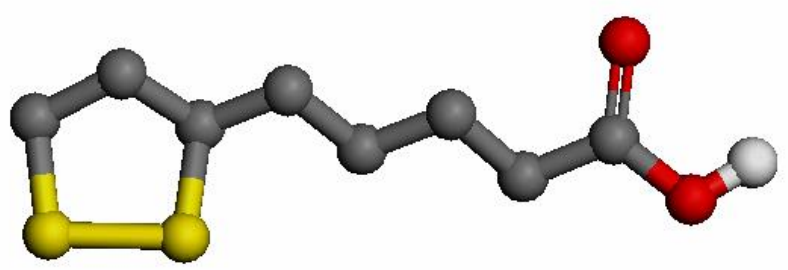

Figure 3: Lipoic Acid

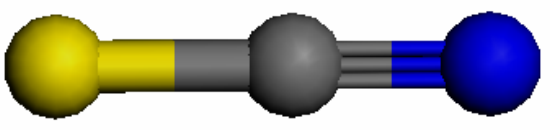

Figure 2: Thiocyanate

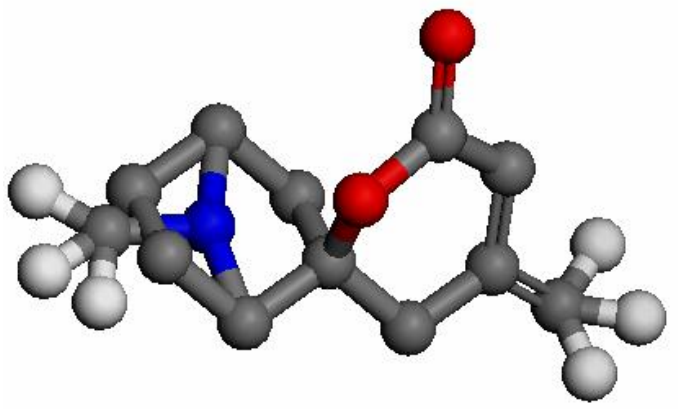

Figure 4: Dioscorin

(Atom legend: Hydrogen $=$ White, Carbon $=$ Ash, Oxygen $=$ Red, Nitrogen $=$ Blue, Sulphur $=$ Yellow)

\section{Some Chemical Functional Essences of Oil-palm}

There are three key nutrient types for the human body; Carbohydrates, Fats, and Protein. In the more popular middle-east crop cradle, as well as wheat as the main source of carbohydrate, they domesticated the olive for fat, cow and other ungulates for protein from milk and meat, etc.

In the case of West African Forest, they domesticated the 'double-oil' palm (Elaeis guineensis) for fat. As far as the world is concerned, the double-oil palm is the most important crop domesticated by forest West Africans.

As the United Nations Food and Agricultural Organization (FAO) describes the current global regard for oil-palm "Because of its economic importance as a high-yielding source of edible and technical oils, the oil palm is now grown as a plantation crop in most countries with high rainfall (minimum $1600 \mathrm{~mm} / \mathrm{yr}$ ) in tropical climates within $10^{\circ}$ of the equator" [18]. It has remained a base food item for Forest West African cuisine and diet. The following are some main nutritional functional essences of palm oils: 


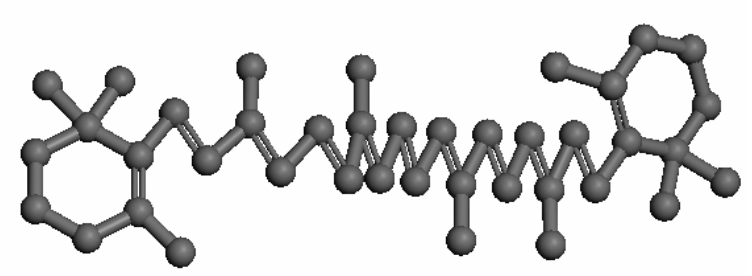

Figure 5: Beta-carotene

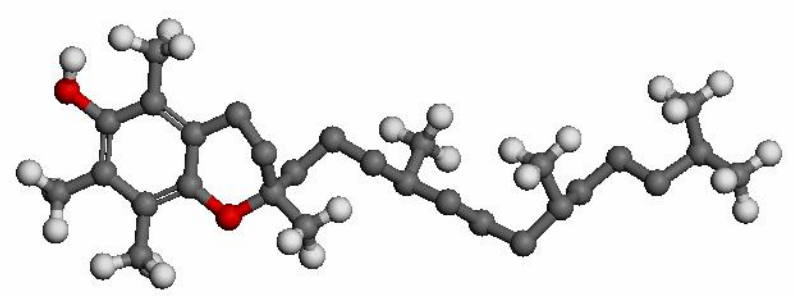

Figure 6: $\alpha$-Tocotrienol

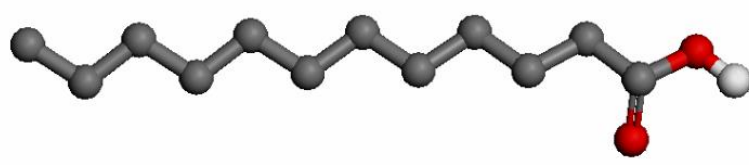

Figure 7: Lauric acid

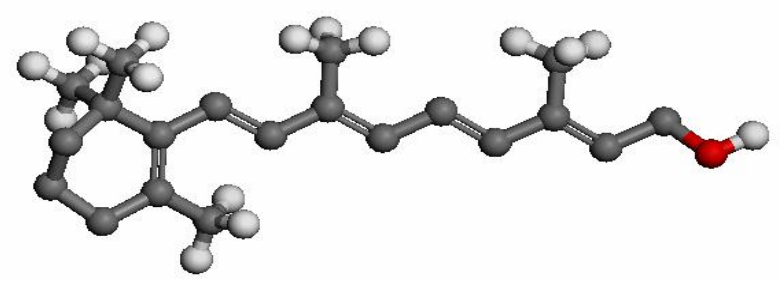

Fig. 8: Retinol

\section{On Health Concerns about Saturated Fats-rich Forest West African Palm Oils.}

Both the key fatty acid in red palm-oil, palmitic acid $\left(\mathrm{C}_{16} \mathrm{H}_{24} \mathrm{O}_{2}\right)$, and the one in palm-kernel oil, lauric acid $\left(\mathrm{C}_{12} \mathrm{H}_{24} \mathrm{O}_{2}\right.$, $)$ are saturated with commensurate poor dietary reputation. People wonder how saturated fats could be healthful, and not obesogenic, as being indicated for the palm oils. But accumulating scientific evidence indicate their healthfulness. For instance, there is homeostatic control of body palmitic acid concentration, which can only be disrupted by some other physiological derangement or obesogenic sedentary lifestyle [19]. Although lauric acid consumption might raise cholesterol level across board, it raises the desirable high-density lipoprotein (HDL) two- and one-half times as fast as the unhealthful low-density lipoprotein (LDL) form. This, in turn, results to healthful low total cholesterol to HDL ratio. Lauric acid, being thermogenic, raises tissue metabolism and consequent weight loss, in addition to the neuroprotective effect of the ketone bodies it generates [20]. With the strong alkalizing powers of tocotrienol and lauric acid, in addition to the plaque-dissolving power of tocotrienol, the palm oils are, demonstrably, healthful for the acidic body of Forest West Africans. 


\section{Nutritional Functions of Leafy Vegetable Complements of the Yampalm Diet.}

Of the three basic nutrients, Carbohydrates come mainly from yams; Fat mainly from oil-palm oils, whence then Protein? Protein indeed comes mostly from vegetable sources, including pulses and other green crops [21]. For Forest West Africans, leafy green vegetables are basic to the diet. The many other sources of additional protein, however, fish and meat are not basic to the Forest West African diet. They are occasional treats, and standard cuisine is not planned around them.

One obvious dietary chemical function from leafy green vegetable sources is folic acid, originating from foliage, by definition. It should be noted that the structure of this alkalizing chemical function is employed to stabilize the highly acidic body of sickle cell anemia sufferers. Sickle cell, a genetic disease, is most prevalent in Forest West Africa. Seasoning with capsaicinrich pepper is routine, and a pepper-less meal is unusual. The bioactive function of pepper, capsaicin, is therefore consumed a lot.

A great proportion of protein is sourced from leafy vegetables, as already indicated. The protein-richest of the leafy green vegetables, Pterocarpus milbraedi, consumed as soup, has $26 \%$ protein by dry weight. Moreover, studies show that by amino-acid constitution its protein is superior to the soya-bean, which is known to be, in turn, superior to beef protein. "The protein in P. mildbraedii (Uha) is higher in quality compared to those in the soybean...cowpea" [22, 23]. It is also the richest in anthocyanin content of the regular green leafy vegetables of the region [24].

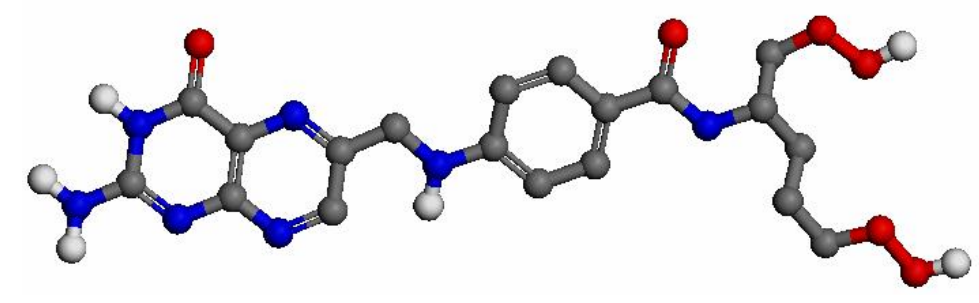

Figure 9: Folic acid

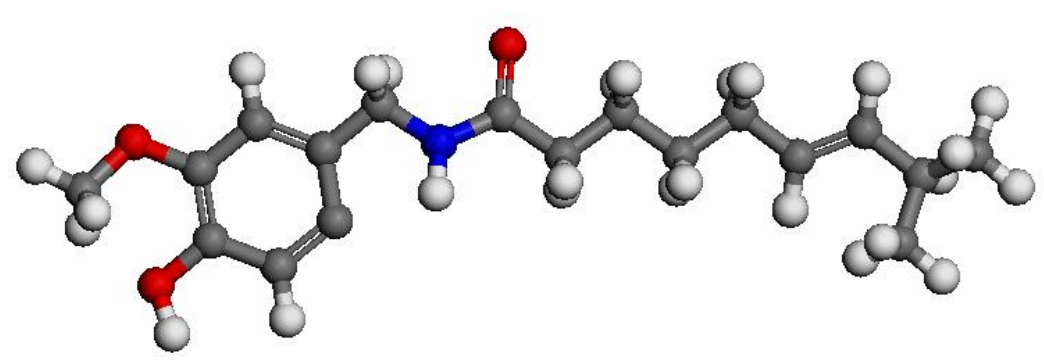

Figure 10: Pepper Capsaicin

\section{The Special Case of Potassium Salt}

Currently salt, usually sodium chloride $(\mathrm{NaCl})$, is routinely used for food seasoning by forest West Africans. This, as reported in the book (The Interesting Narrative, 1789) by Olaudah Equiano, a Forest West African freed slave, has not always been the case. He reported that the Igbo, for instance, got their salt from wood-ash [25]. That would make the ancient peoples of Forest West Africa, mostly, traditional users of potassium salts. That is salts rich in potassium ions: $\mathrm{K}^{+}$. This is 
still significantly the case if one considers the wood-ash extracts employed in cooking hard-shell seeds/pulses, breadfruit, and preparation of puddings and salads. But Equiano's observation is highly significant. Potassium is more alkaline than sodium and so better for the acidic Forest West African body. Modern Africans and their Diaspora are known to have poor relative capacity to excrete sodium ions, $\mathrm{Na}^{+}$, through his kidneys. This is most likely the consequence of ancient adaptation to the potassium salt diet [26].

\section{Forest West African Diet Is Highly Alkalizing Diet.}

A general overview of the forest West African Diet from the staple yam (Dioscorea spp.) to the potassium-based salt for seasoning suggests a general character of Forest West African Diet as Highly Alkalizing Diet. This diet that would be significantly suitable for peoples of the hot and humid tropical forests of the world, which is consistent with the fact that forest West Africans have successfully adopted other tropical crops. Cassava (Manihot esculenta) has a moderate glycemic index and is rich in thiocyanate like dioscorea and coconut (Cocos nucifera) oil is rich in lauric acid. The main physiological functions of Forest West African diet include, among others:

1. Alkalizing (powerful reducing agents)

2. Ketogenic (generates ketone bodies, say from medium-chain fatty acid as lauric acid); can replace glucose for brain/nerve metabolism in acidic bodies.

3. Bioelectrical modulation. For example, ketone bodies from lauric acid are resonancestabilized structures that are capable of modulating charges in the system.

\section{Some Normal Forest West African Diseases}

Like the rest of humanity, infectious diseases, particularly malaria, have been endemic with the Forest West African People for a long time. Besides, Sicke cell anemia is the more unique and fundamental genetic disease. The evidence suggests that Sickle cell Disease (SCD) is a disease that came about as a result of genetic adaptation to the West African tropical forest environment. The two key stressors that, most probably, brought about SCD among tropical peoples are:

I. Biogeographical or ecogeographical stress: hot, humid, environments with high solar irradiation required people to use metabolic energy, and less of it, in a particular way and have particular physiognomy, to function efficiently.

II. Zoonotic stress (blood-feeding malarial parasites; plasmodium spp., that cannot thrive in more acidic blood, as in those that carry the gene, compared to those that do not carry the gene, but have less acidic blood). SCD is the great, genetic, nutritional and health marker of Forest West African physiology [27].

A careful overview of the tables below on the initial metabolism of glucose; glycolysis, first to pyruvate, reveals some problem with conversion of pyruvate to citric acid cycle products, as lactate, instead builds up. Apparent is the implication that the pyruvate dehydrogenase complex (PDC) that converts pyruvate to acetyl CoA and tissue respiration is probably deranged. The fact that the PDC is deranged in SCD has indeed been reported in the literature [28]. The derangement of PDC results to build up pyruvic acid behind the PDC complex. Pyruvic acid and lactic acid are in a dynamic equilibrium that more favors conversion of pyruvic acid into lactic acid. So, both pyruvic acid and lactic acid build up in SCD [29]; (see Table 2). The backpressure builds up until 
glucose itself cannot be metabolized (see Table 1). Sickle Cell anemia can, therefore, be considered a form of functional diabetes when that is understood as a body's inability to metabolize glucose efficiently. The compensatory over-utilization of fructose, leading to low blood levels of fructose in inverse relationship to glucose in SCD, is to be noted (fructose, unlike glucose, enters cells by passive transport).

Table 1: Plasma Glucose and Fructose Levels in Different Sickle Cell States.

\begin{tabular}{|c|c|c|c|}
\hline $\begin{array}{c}\text { Sickle Cell } \\
\text { StatState }\end{array}$ & $\begin{array}{c}\text { Number of } \\
\text { Subjects In } \\
\text { Group }\end{array}$ & $\begin{array}{c}\text { Plasma Glucose } \\
\text { Level, mg/dl }\end{array}$ & $\begin{array}{c}\text { Plasma Fructose } \\
\text { Level, mg/dl }\end{array}$ \\
\hline $\mathrm{HbAA}$ & 35 & $70.10 \pm 7.50$ & $1.32 \pm 0.08$ \\
\hline $\mathrm{HbAS}$ & 32 & $74.75 \pm 6.20$ & $1.25 \pm 0.05$ \\
\hline $\mathrm{HbSS}$ & 34 & $78.59 \pm 4.20$ & $1.09 \pm 0.05$ \\
\hline $\mathrm{HbSSc}$ & 33 & $84.80 \pm 4.10$ & 0.990 .04 \\
\hline
\end{tabular}

Table 2: Lactate and Pyruvate Levels in Different Sickle Cell States.

\begin{tabular}{|c|c|c|c|c|}
\hline Sickle Cell State & HbAA & HbAS & HbSS & HbSS-crisis \\
\hline Lactate Level, mM-L-1 & $0.74 \pm 0.19$ & $0.75 \pm 0.23$ & $27.60 \pm 1.39$ & $31.40 \pm 2.56$ \\
\hline Lactate ratio & 1.00 & 1.01 & 37.30 & 42.43 \\
\hline Pyruvate Level, mM-L-1 & $0.11 \pm 0.02$ & $0.11 \pm 0.03$ & $2.03 \pm 0.05$ & $2.08 \pm 0.11$ \\
\hline Pyruvate ratio & 1.00 & 1.00 & 18.45 & 18.91 \\
\hline Lactate/pyruvate & 7.01 & 7.02 & 13.60 & 15.07 \\
\hline
\end{tabular}

This has the following, logical, adverse metabolic and health implications:

1. Sickle cell disease, SCD, sufferers cannot metabolize glucose well, which builds up in their system.

2. Sickle cell gene carriers are more prone to diabetes.

3. The metabolism of cells that depend solely on glucose; such as red blood cell and nerve cells, would be compromised in SCD sufferers. So, anemia and nerve problems such as stroke would be more prevalent.

4. Because acetyl-CoA metabolism, which generates most of the body energy is compromised, anergy would be a generic problem for SCD sufferers.

5. The buildup of pyruvic and lactic acids, due to malfunctioning PDC, would result in metabolic acidosis and related syndromes.

6. The body, usually, converts excess lactate into fat; through the lactate shuttle. Forest West Africans, who build up lactate in their acidic body would, logically, be more prone to obesity and the metabolic syndrome associated with it in the presence of excess food. 
On the positive side:

1. The acidic body of the Forest West African would not allow certain micro-organisms that are susceptible to destruction by acidic environments to thrive.

2. The malarial parasite; Plasmodium spp, does not thrive in acidic, or electron-poor, environment. So, forest West Africans would be more resistant to malarial attacks. That is as long as they do not buildup fat in their system on which the organism thrives [30]. That explains why the electron-rich amino acid, Phenylalanine (see Fig 10) is used to treat SCD but promotes cerebral malaria. On the other hand, the amino acid L-Arginine does the opposite of what phenylalanine does. It produces the powerful oxidizing agent, nitric oxide (NO), which kills malaria parasites. NO is in very low concentration in the blood of severe malaria patients $[31,32,33]$. The active

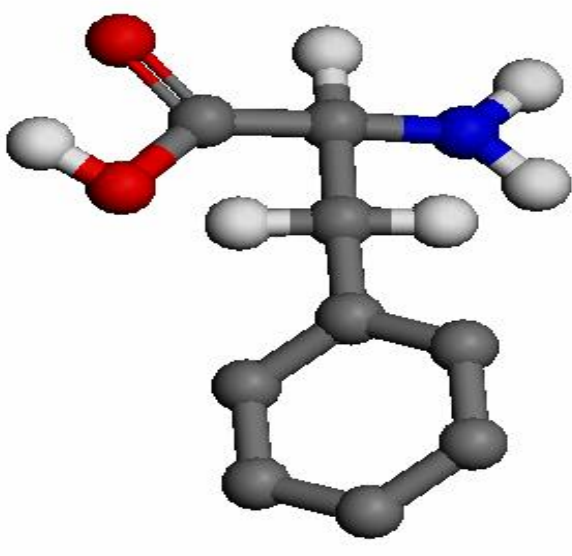

Figure 11: Electron-rich Phenylalanine substance in the beans Fiofio; Cajanus cajan, fed to SCD sufferers to stabilize them, is phenylalanine. Generally, antisickling agents are reducing agents, while antimalarials are oxidizing agents. An example of an oxidant used as an antimalaria is the current most popular substance for malarial treatment: artemisinin (see Fig 11). It is a peroxide, an oxygen-rich molecule, like hydrogen peroxide $\left(\mathrm{H}_{2} \mathrm{O}_{2}\right)$. It is the active oxygen it releases that kills the malarial parasite. Hydrogen peroxide is not used for the same purposed only because it will release the oxygen too fast, as to burn the cells. But other peroxides that release their oxygen at more appropriate rates or efficient formulations of oxygen could be used effectively for the same purpose.

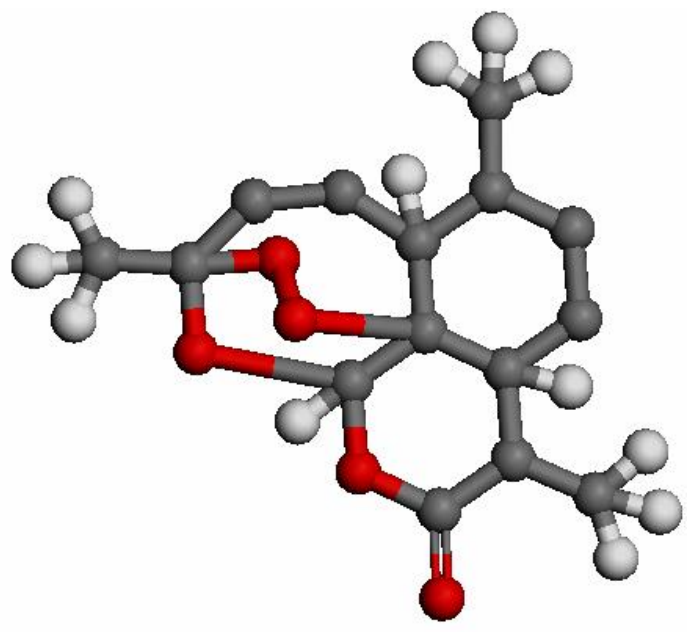

Figure 12: Artemisinin; A Peroxide Antimalarial Molecule

\section{Circumstances of Forest West African Adoption of Alien Diet}

It is shown that consistent with their tropical forest adapted physiology, Forest West Africans have a diet regime, very rich in fruits and vegetables, that is highly alkalizing [34]. This is efficient, as 
neutralizing factor, for their tropical acidic body system. In the last four hundred years, due to the trans-Atlantic slavery and European influence, Forest West Africans have adopted an alien diet, 'modernization diet'. Evidence is that this new diet regime is inconsistent with Forest West African physiology and good health.

\section{Review of the European Diet Type in Relation to Forest West Africans}

At the core of the European diet is Wheat (Triticum aestivum), Bread of the Fertile Crescent, with dairy products that are part of the mix for protein and oil comes mostly from olive (Olea europae). When there is a liberal component of fruits and vegetables and fish, the classical Mediterranean Diet is realized. However, other variations of the diet that are heavier in calories exist, like the Nordic diet. The Nordic diet emphasizes canola oil more than olive oil, fatty fish more than meat, and wheat and milk are always there. Wheat gluten and milk lactose are at the heart of Forest West African crises of poor adaptability to the European diet.

\section{Chemical Functional Basis of Wheat and Milk Diet Challenges to Forest West Africa.}

The essentials problems of wheat and milk diet for forest West Africans come from 1. Gluten opioids in wheat 2. Lactose in milk and 3. Casomorphin Opioids in Milk. Fig. 12 shows the lactose molecule.

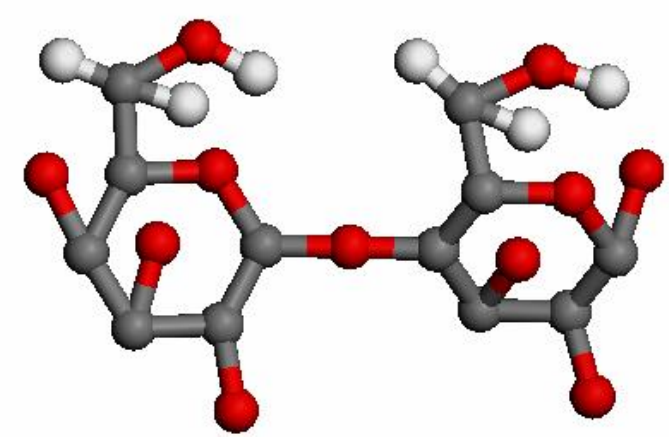

Figure 13: Lactose A high percentage of the people of Forest West Africa cannot digest lactose because they lack the enzyme, lactase, for the digestion of lactose. In a study, Lactose tolerance was tested in four major ethnic groups in Nigeria, West Africa. "The data indicates that $99 \%$ of the Yoruba and $96 \%$ of the Ibo after the age of $1 \frac{1}{2}$ to 3 years malabsorb lactose, whereas only $64 \%$ of the Hausa and Fulani show malabsorption. But nomadic Fulani, who are migratory cattlemen, show only $20 \%$ malabsorption." [35, 36]. A study done in the United States the same year shows that the overwhelming majority of African Americans are lactose intolerant $[37,38]$. This shows that this otherwise normal genetic condition for non-baby mammals cannot be reversed in a few generations of drinking milk and trying to adapt. The lactose intolerance rates among Asians are also high, reaching 90\% [39].

The summary of all these is that some bioactive wheat substances disrupts some people's metabolic systems when they are not adapted to it. Wheat is a great crop being the main grain of the temperate peoples. It is energy-rich and contains a very high fiber content that is very good for the colon [40]. However, it is best for those most adapted to it, which does not seem to include Forest West Africans. Forest West Africans are adapted to yams, fruits, and leafy green vegetables and are, therefore, more susceptible to gut diseases and metabolic syndromes, including obesity, diabetes and hypertension, associated with the Wheat-Milk diet of modernity [41, 42, 43].

\section{Wheat and Milk as Agents of Modernization Diseases Afflicting Forest West Africa}

It has been noted by an observer that "The history of wheat parallels the history of chronic disease and obesity across the world" [44]. These chronic diseases are now more prevalent in Forest West 
Africans and their Diaspora. This is evident in the statistics for related metabolic syndrome. Obesity, diabetes, dyslipidemia, hypertension are metabolic syndrome-related diseases, influenced by diet, as already indicated. The belly-fat associated with metabolic syndrome has been called 'wheat belly' and 'gluten belly' [45].

It is noted that, independently, lactose in milk and wheat can cause lower bowel inflammation. Taken together, as has become the breakfast culture of city-dwelling peoples across the world, the potential for lower bowel inflammation is compounded for those who are not adapted to either. This would be particularly the case with those whose traditional foods are not wheat and milk based.

The evidence points to the validity of these surmises for Forest West Africans. Lower bowel inflammation, commonly mistaken for hemorrhoids or pile, is now endemic in West African cities. This is particularly the case with sedentary workers. This is a classic case of a modernization disease because this was not a serious health problem in West Africa before encounter with alien diet and sedentary professions. Hemorrhoids incidence is known to correlate such metabolic syndrome disease as obesity [46, 47]. The anecdotal experience is that as soon as someone afflicted by this 'pile' subtracts wheat (bread, cake, biscuit, etc.) and milk from their diet, the symptoms recede.

\section{THE TRANSATLANTIC AFRICAN DIET LABORATORY AND MODERNIZATION DISEASES}

The trans-Atlantic slave trade took Africans to the Americas and Europe. This is also the uprooting of African people from the 'Yam-palm oil-foliage' diet culture to a 'Wheat-meat-milk' diet culture. What this has created is a Grand Diet Laboratory, with tens of millions of subjects, that allows the study of the reaction of the Forest West African body type to alien diet, other than his adapted yam, foliage and palm oils. The studies are generating a lot of remarkable data from the Caribbean, the Americas and Europe.

One of the well-established findings is that Forest West African Diaspora suffer more from inappropriate diet and lifestyle induced metabolic syndromes than any other peoples [48, 49, 50], which is expected! This helps explain what is happening to township-dwelling Africans who adopt the wheat-meat-milk dietary regime. Those in the Caribbean who consume a diet with more African components appear better off health-wise than, say, those in North America who have transited more significantly into a more Western diet regime.

Researchers found: "African-American children were sensitized to at least one food allergen three times more often than Caucasian children". "Asian and Black children were more likely to have a convincing history of food allergy" [51].

The Standard American Diet is mostly European type diet. It is alien to African and Asian body types, hence the greater allergic reactions to that diet by these non-European peoples. The general diet-related challenges, such as the greater prevalence of the metabolic syndrome including obesity, dyslipidemia, diabetes, hypertension, etc., observed among African Americans, can also be accounted for by the facts outlined above about differences in physiology interacting with differences in historical diet cultures. When these syndromes appear among Forest West Africans, or other people from tropical parts of the world, they are termed 'modernization' diseases. 


\section{Managing Modernization Diet Related Diseases Among Africans.}

A remarkable experiment carried out by University of Pittsburg research team points to the possible ameliorative approach to modernization diseases, such as the metabolic syndrome among Africans. O'Keefe and his colleagues picked populations of African Americans and rural Africans and switched their usual diets for a period and observed the outcomes. "In this time, the Africans consumed traditional American food-meat and cheese high in fat content-while African Americans took on a traditional African diet-high in fiber and low in fat, with plenty of vegetables, beans, and cornmeal, with little meat". Unambiguously, the Africans started developing the usual diseases of African Americans, like colon cancer. The African-Americans on rural Africans' diet experienced healing, with measured remission of symptoms [52]. It has to be noted that supplementation with folic acid, the potent reducing power supplier, which was used to manage SCD, had very positive effect [53]. Forest West Africans, away from the liberal supply of green leafy vegetables, should supplement their diets with regular supplies of folic acid.

The logical inference is clear. If Africans all over the world go back to the traditional African diet to which they are genetically adapted, the problem of 'modernization' diseases, particularly the metabolic syndrome, among them will recede. For Forest West Africans, this would include a diet without wheat, milk and excess meat. Yams, palm oils, and green-leafy vegetables as a base would, like the Pittsburgh University experiment demonstrated, restore them to a healthier life. That is a life free from life-shortening metabolic syndrome.

\section{Folk Experience Had Anticipated Result of African Diet Switch Experiment}

An eighteenth-century freed slave from West African, Olaudah Equiano, had made some interesting observations on the Forest West African diet during his time. Equiano's book, The Interesting Narrative (1789), had given a hint on one reason why African kidney may have difficulty excreting sodium. African kidneys are more adapted to potassium, which was the salt type he reported the people mostly used at the time.

Among Africans Americans, the folklore still presents yam as an 'elixir'. Alice Walker's The Color Purple and Bell Hooks' Sisters of the Yam make the case [54, 55]. In Walker's book, an episode is described, during the slave era, in which a little girl Henrietta was not thriving. The solution the African slaves knew was to do what was done in Africa with issues like that, which was to, relentlessly, feed the girl lots of yam meals by all means possible.

The Igbo of Forest West Africa have a saying that backs the above observation; "Ihe eji ama mgbe ogwu ghere wu ji abanyere ya!" The sure proof that the boiling herbal medicine is done is that the co-boiled yam is done!". This shows that, like among African Americans of an earlier generation, yam was a standard component of Forest West African herbal preparations. Yam is key food as well as a key medicine, to which people had genetically adapted over a very long time.

In her book, Sisters of the Yam (1993), Bell Hooks presents The Yam as a medicinal magic wand, an instrument of socially sickened Africans' holistic mind, body and spirit healing. A return to yam, in effect, is a return to wholeness: a healthy and balanced life. This observation is consistent with Forest West African tendency to equate agriculture itself with yam, such that the Agricultural Festival is the Yam Festival. Equating yam with medicine, on such a broad scale, suggests there are bioactive functions in yam that are very healthful to Forest West African body system. The Forest West African diet culture, such as yam (Dioscorea spp.) consumption, is relatively maintained in the West Indies by the African Diaspora with healthful results [56]. 


\section{More Reasons for Africans' Return to Their Dietary Roots.}

Some Chinese researchers have looked at what would happen to rat models of the metabolic syndrome when treated with the yam protein dioscorin. Their finding: "Yam dioscorins exhibit improved metabolic syndrome activities in obese rats..." [57, 58]. The same test carried out with dioscorin to test hypertension control proved efficacious [59].

Another bioactive function that makes yam (dioscorea spp.) a good functional food for Forest West Africans is thiocyanate. A study on this concluded that Sickle cell anemia is much more severe in African Americans than Africans on the continent because of the lack of adequate levels of thiocyanate in the American diet, whereas Africans get adequate levels of this efficacious antisickling agent from yam [60].

A key point of reflection is Basden's observation that Igbo, indeed, had lots of cows when the Europeans arrived in the Lower Niger at the turn of the $20^{\text {th }}$ Century. The European, concerned that the natives needed more protein in their diet than was observable, tried to persuade them to drink cow milk. But they would not be persuaded to drink the abundant cow milk from cows they reared [61]. This was, most probably, because of earlier experience with lactose intolerance

\section{SUMMARY}

Forest West Africa is the domestication cradle of two important food crops; yam (Dioscorea spp.) and oil palm (Elaeis guineensis). This implies possible adaptation to the functional essences of these crops at the genetic and epigenetic levels over millennia by indigenous peoples. Evidence demonstrates that Forest West Africans are adapted to a diet of yam, oil-palm and associated crops. Transiting from this adapted dietary regime to one based on gluten-rich wheat and lactose-rich milk has created a public health challenge, the Metabolic Syndrome. The indigenous Yampalm diet type is characterized by bioactive chemical functions that are alkalizing, ketogenic and bioelectrical modulating; healthful to an acidic and oxidizing tropical physiology.

With return to a yam and palm-based diet and the minimization of wheat gluten and milk lactose, the epidemic of the metabolic syndrome that currently challenges Forest West Africa and her global diaspora would be significantly obviated or remediated. The bioactive functions of that diet can be extracted and used for their contemporary diet supplementation. Such supplements could include the metabolic syndrome remediating dioscorin from yam and arterial plaque removing tocotrienols from red palm oil. From cross-study of contemporary African and AfricanAmerican diets in relation to health, genetically or epigenetically adapted diets appear to avail optimal health to indigenous people compared to adopted modernization diet.

List of abbreviations: HDL, High-density lipoprotein; LDL, Low-density lipoprotein; PDC, Pyruvate dehydrogenase complex; SCD, Sickle cell Disease; FAO, United Nations Food and Agricultural Organization

Competing interests: The authors declare no competing financial interest.

Acknowledgements: The author would like to thank the authorities of the Federal University of Technology, Owerri, for supporting in the preparation of this paper with funding from the university Lectures Committee. 


\section{REFERENCES:}

1. Osuagwu CG: Characterization of Forest West African Diet Type and Management of Related Modernization Diseases; $34^{\text {th }}$ University Public Lecture, 2019. FUTO Press Ltd, Owerri.

2. Rastogi GK, Sawhney RC: Thyroid function in changing weather in a subtropical region; Metabolism, 1976; 25(8): 903-8.

3. Roberts D F: Body weight, race and climate; American Journal of Physical Anthropology, 1953; 11 (4): 533-558.

4. Ruff CB: Morphological adaptation to climate in modern and fossil hominids; Yearbook of Physical Anthropology, 1994; 37: 65-107.

5. Schreider E: Geographical distribution of the body-weight/body-surface ratio; Nature, 1950; 165 (4190): $286 \mathrm{~S}$.

6. Roberts DF: Climate and Human Variability (2nd ed.), 1978. Menlo Park, CA: Cummings.

7. Mediterranean Diet for a Healthy Heart [https://www.mayoclinic.org/healthylifestyle/nutrition-and-healthy-eating/in-depth/mediterranean-diet/art-20047801] Retrieved $10 / 11 / 2019$

8. The Nordic Diet: An Evidence-Based Review [https://www.healthline.com/nutrition/thenordic-diet-review]

9. Lev-Yadun S, Gopher A, Abbo S: The cradle of agriculture lay within a small region of the Fertile Crescent...began in the 7th millennium B.C; Science, 2000 288(5471):1602-1603.

10. Civan P, Craig H, Cox CJ, Brown TA: Three geographically separate domestications of Asian rice; Nature Plants 1, 2015; Article number: 15164.

11. Kistler L, Maezumi SY, Gregorio de Souza J, Przelomska NAS, Malaquias Costa F, Smith $\mathrm{O}$, Loiselle $\mathrm{H}$, et al.: Multiproxy evidence highlights a complex evolutionary legacy of maize in South America Zea mays; Science, 2018: 362(6420):1309-1313.

12. Hardigan MA, Laimbeer FPE, Newton L, Crisovan E, Hamilton JP, Vaillancourt B, WiegertRininger K, et al.: Genome diversity of tuber-bearing Solanum uncovers complex evolutionary history and targets of domestication in the cultivated potato; PNAS, 2017; 114 (46) E9999-E10008.

13. Dolores RP: The Origins of Plant Cultivation and Domestication in the New World Tropics Patterns, Process, and New Developments; Manihot esculenta; Current Anthropology, 2011; 52, Supplement 4.

14. Scarcelli N, Cubry P, Akakpo R, Thuillet A, Obidiegwu J, Baco MN, Otoo M, Sonke B, et al.: Yam genomics supports West Africa as a major cradle of crop domestication; Science Advances;, 2019; 5 (5) eaaw1947.

15. Cubry P, Tranchant-Dubreuil C, Thuillet AC, Monat C, Ndjiondjop MN, Labadie K, Cruaud C, et al.: The rise and fall of African rice cultivation revealed by analysis of 246 new genomes; Current Biology, 2018; 28(14): 2274-2282

16. Bobadoye MF, Enujiugha VN: Evaluation of glycaemic indices of some selected Nigerian boiled yam (Dioscorea spp); Applied Tropical Agriculture, 2016; 21 (1).

17. Olajumoke OL, Agiang MA, Williams IO, Alozie YE, Eteng MU: Mineral and toxicant levels in yam (Dioscorea rotundata) diets; European Journal of Experimental Biology, 2014; 4(1): 656-61. 
18. FAO [www.fao.org/3/y4355e/y4355e03.htm] Retrieved 10/10/2019.

19. Carta G, Murru E, Banni S, Manca C: Palmitic Acid: Physiological Role, Metabolism and Nutritional Implications; Frontiers in Physiology, 2017; 8:902.

20. Carty MF, DiNicolantonio JJ: Lauric acid-rich medium-chain triglycerides can substitute for other oils in cooking applications and may have limited pathogenicity; Open Heart; 3(2): e000467.

21. FAO: http://www.fao.org/pulses-2016/news/news-detail/en/c/337107/

22. Akinyeye RO, Oluwadunsin A, Omoyeni A: Proximate, mineral, anti-nutrients, phytochemical screening and amino acid compositions of the leaves of pterocarpus mildbraedi harms; Electronic Journal of Environmental, Agricultural \& Food Chemistry, 2011; 10(1):1848-1857.

23. Onyeka EU, Nwambekwe IO: Phytochemical profile of some green leafy vegetables in South East Nigeria; Nigerian Food Journal, 2007: 25 (1); 67-76.

24. Akpanyung EO, Udoh AP, Akpan EJ: Chemical composition of the edible leaves of Pterocarpus mildbraedii; Plant Foods Hum Nutr. 1995; 48(3):209-15.

25. Equiano O: Equiano's Travels: The Interesting Narrative of the Life of Olaudah Equiano or Gustavus Vassa the A f r i c a n; London, Heinemann, 1967.

26. Weinberger MH: Racial differences in renal sodium excretion: relationship to hypertension; Am J Kidney Dis, 1993; 21 (4 Suppl 1), 41-5.

27. Osuagwu CG: Elevated System Energy Expenditure in Sickle Cell Anemia; in Anemia, 2012; Donald S. Silverberg, IntechOpen; doi: 10.5772/31287.

28. Kato GJ, Nouraie SM, Gladwin MT: Lactate dehydrogenase and hemolysis in sickle cell disease; Blood, 2013; 122(6), 1091-1092.

29. Osuagwu CG: Primary Pyruvate Acidosis in Sickle Cell Anemia; Nigerian Journal of Biochemistry and Molecular Biology, 2009; 24 (2), 48 - 51.

30. Mohanty S, Mishra SK, Das BS, Satpathy SK, Mohanty D, Patnaik JK, Bose TK: Altered plasma lipid pattern in falciparum malaria; Ann Trop Med Parasitol:, 1992; 86(6); 601-6.

31. Fuchs S, Behrends V, Jacob G. Bundy JG, Andrea Crisanti A, Nolan N: Phenylalanine metabolism regulates reproduction and parasite melanization in the malaria mosquito; PLoS One;2014; 9(1): e84865.

32. Lopansri BK, Anstey NM, Stoddard GJ, Mwaikambo ED, Boutlis CS, Tjitra E, Maniboey $\mathrm{H}$, et al.: Elevated Plasma Phenylalanine in Severe Malaria and Implications for Pathophysiology of Neurological Complications; Infect Immun, 2006; 74(6):3355-9.

33. Enwonwu CO, Afolabi BM, Salako LA, Idigbe EO, Al-Hassan H, Rabiu RA: Hyperphenylalaninaemia in children with falciparum malaria; QJM: An International Journal of Medicine, 1999; 92: 495-503.

34. Asgard R, Rytter E, Samar Basu S, Abramsson-Zetterberg L, Lennart Moller L, Vessby B: High intake of fruit and vegetables is related to low oxidative stress and inflammation in a group of patients with type 2 diabetes; Scand J Food Nutr; 2007; 51(4): 149-158.

35. Kretchmer N, Ransome-Kuti O, Hurwitz R, Dungy C, Alakija W: Intestinal absorption of lactose in Nigerian ethnic groups; The Lancet;1971; 2(7721):392-5. 
36. Ransome-Kuti O, Kretchmer N, Ruth Hurwitz R, Dungy C, Alakija, W: Absorption of lactose by various Nigerian ethnic groups, 1971. Pediatric Research, 1971; 5: 388-389.

37. Paige DM, Bayless TM, Ferry GD, Graham GG: Lactose malabsorption and milk rejection in Negro children; Johns Hopkins Med J; 1971; 129(3):163-9.

38. Cardell NS, Hopkins MM: The Effect of Milk Intolerance on the Consumption of $\quad$ Milk by Slaves in 1860. The Journal of Interdisciplinary History, 1978; 8 (3): 507-513.

39. Alford SC: Lactose Intolerance in Asians; Nature; 1969; 221: 562-563.

40. Manning AP, Heaton KW, Harvey RF: Wheat fibre and irritable bowel syndrome: A controlled trial. Lancet, 1977; 2(8035):417-8.

41. Brar P, Lee AR, Lewis SK, Bhagat G, Green PH: Celiac disease in African-Americans; Dig Dis Sci, 2006; 51(5):1012-5.

42. Hall WD, Clark LT, Wenger NK, Wright JT Jr, Kumanyika SK, Watson K, Horton EW, et al.: The Metabolic Syndrome in African Americans: a review; Ethn Dis, 2003; 13(4):41428.

43. Clark LT, El-Atat, F: Metabolic syndrome in African Americans: implications for preventing coronary heart disease; Clin Cardiol, 2007; 30(4):161-4.

44. Three Hidden Ways Wheat Makes You Fat [https://drhyman.com/blog/2012/02/13/threehidden-ways-wheat-makes-you-fat/]

45. Wheat Belly [https://www.webmd.com/diet/a-z/wheat-belly-diet-review]

46. Understanding Causes, Symptoms of Piles [https://guardian.ng/features/understandingcauses-symptoms-of-piles/]

47. Riss S, Weiser FA, Schwameis K, Riss T, Mittlbock M, Steiner G, Stift A: The prevalence of hemorrhoids in adults; Int J Colorectal Dis, 2012; 27 (2): 215-20.

48. Overweight African-Americans May be Addicted to Opioids in Wheat-Gluten; [http://soulwisdom.blogspot.com/2012/01/overweight-african-americans-suffer.html]

49. Saab KR, Kendrick J, Yracheta JM, Lanaspa MA, Pollard M, Johnson RJ: New Insights on the Risk for Cardiovascular Disease in African Americans: The Role of Added Sugars; J Am Soc Nephrol, 2015; 26(2): 247-257.

50. Kiple KF, Kiple VH: The African Connection: Slavery, Disease and Racism; Phylon, 1980; 41(3):211-22.

51. Gupta RS, Springston EE, Warrier MR, Smith B, Kumar R, Pongracic J, Holl JL: The Prevalence, Severity, and Distribution of Childhood Food Allergy in the United States; Pediatrics, 2011; 128(1):e9-17.

52. O'Keefe SJ, Li JV, Lahti L, Ou J, Carbonero F, Mohammed K, Posma JM, et al.: Fat, fibre and cancer risk in African Americans and rural Africans, 2015. Nature Communications, 2015; 6:6342.

53. Chan YM, Aufreiter S, O'Keefe SJ, O'Connor DL: Switching to a fibre-rich and low-fat diet increases colonic folate contents among African Americans; Appl Physiol Nutr Metab; 2019; 44(2):127-132.

54. Walker A: The Color Purple; Harcourt Brace Jovanovich, 1982.

55. Hooks B: Sisters of the Yam: Black Women and Self-recovery. South End Press, 1993. 
56. Prof Morrison tells why Jamaicans run so fast: Yam and Bananas, 2011[ http://www. jamaicaobserver.com/sport/Prof-Morrison-tells-why-Jamaicans-run-so-fast_9306187]

57. Shih SL, Lin YS, Lin SY, Hou WC: Effects of yam dioscorin interventions on improvements of the metabolic syndrome in high-fat diet-induced obese rats; Botanical Studies; 2015; $56(1): 4$.

58. Wu GC, Lin SY, Liang HJ, Hou WC: 135-Day interventions of yam dioscorin and the dipeptide Asn-Trp (NW) to reduce weight gains and improve impaired glucose tolerances in high-fat diet-induced c57bl/6 mice; J. Agric. Food Chem, 2018; 66 (3); 645-652

59. Hsu FL, Lin YH, Lee MH, Lin CL, Hou WC: Both Dioscorin, the Tuber Storage Protein of Yam (Dioscorea alata cv. Tainong No. 1), and Its Peptic Hydrolysates Exhibited Angiotensin Converting Enzyme Inhibitory Activities; J. Agric. Food Chem, 2002; 50 (21); 6109-6113.

60. Agbai O: Anti-Sickling Effect of Dietary Thiocyanate in Prophylactic Control of Sickle Cell Anemia; J Natl Med Assoc, 1986; 78(11): 1053-1056.

61. Basden GT: Notes on the Ibo Country, Southern Nigeria; The Geographical Journal, 1925; 65(1): 32-41. 